\title{
IS 'NECESSARILY' REALLY NECESSARY? EVIDENCE OF SCHEDULE E EXPENSES DEDUCTIONS AMONGST IRISH EMPLOYEES
}

\author{
Paula Farrelly, Thomas McCluskey and Pauline Willis \\ Dublin City University
}

\begin{abstract}
Cection 114 of the Taxes Consolidation Act 1997 restricts income tax relief Sfor employee expenses to those which employees are necessarily obliged to incur in the performance of their duties. Despite the rigidity of this rule, income tax relief is granted for certain flat rate expenses. This paper explores the inconsistencies in the negotiation, granting and publicising of these concessionary allowances and investigates the extent to which employee taxpayers are remiss in claiming them. Responses obtained from 557 taxpayers demonstrate confusion amongst taxpayers as to their entitlements and it is recommended that the relief should be granted at source.
\end{abstract}

\section{INTRODUCTION}

The history of taxation commentary has been dominated by analyses of judicial decisions on the interpretation of case law and statutes and investigations into behavioural attitudes to tax compliance amongst taxpayers. Richardson (2005) observed that most of the academic research on tax compliance has focused on the field of fiscal psychology, which has examined the influence of non-economic variables (for example, ethics, perceived fairness and perception of tax evasion) on tax compliance behaviour (for example, Kim, Evans and Moser, 2005; Cummings, Martinez-Vazquez, McKee and Torgler, 2006; Richardson, 2006; Fortin, Lacroix and Villeval, 2007; Verboon and Van Dijke, 2007).

One of the most neglected topics in the tax research literature is the non-takeup of available tax allowances. This is somewhat surprising given the extensive literature in the related field of social security entitlements which reports that a 
Farrelly, McCluskey and Willis

substantial number of citizens eligible for social security assistance simply do not claim their entitlements (see, for example, Ruggles and Michel, 1987; Giannarelli and Clark, 1992; Blank and Ruggles, 1994, 1996). There have been a number of United States (US)-based studies on the failure to claim tax reliefs which conclude that the nature and complexity of tax regulations appear to inhibit taxpayers in making claims for tax deductible expenses to which they are entitled. Specifically, studies by de Bartolome (1995), Chetty and Saez (2009) and Saez (2010) noted widespread confusion amongst taxpayers regarding allowable tax deductions and credits arising from layers of complex regulations in the Internal Revenue Service Code and various statutory instruments. Krause (2000) noted that complexity, uncertainty, ignorance and burdensome documentation requirements deterred taxpayers from taking advantage of legitimate deductions and credits and these were the primary cause for the non-take-up of available tax reliefs. Findings by Madrian and Shea (2001) and Choi, Laibson, Madrian and Metrick (2003) observed that in the context of employee savings plans, taxpayer inertia was amongst the most common reasons for many taxpayers failing to make efficient tax investment decisions so as to minimise tax liabilities. Scholz (1993) examined the participation rate of federal income taxpayers in 1990 for the earned income tax credit and noted that between 14 and 20 per cent of eligible taxpayers did not claim the credit. The paper concluded that the taxpayers least likely to file claims when eligible were those who were entitled to smaller credits, had a greater share of their earnings composed of self-employment income and lived in states without state income taxes. However, Ramsden and Donnay (2001) noted that well-publicised reforms to the tax regime for tax deductions in respect of political contributions in various US state legislature elections appear to have broadened the base of taxpayer claims for allowable deductions for political contributions, particularly amongst middleclass taxpayers.

Similarly, in the United Kingdom (UK) a report by the Department of Work and Pensions (DWP) (Department of Work and Pensions, 2008) concluded that the main reasons why individuals do not claim their entitlements to tax allowances is inertia and a perception that the expected refund will be negligible. The DWP report is consistent with the comments of the Irish Minister of Finance in relation to deposit interest retention tax. In reply to a question as to why certain elderly taxpayers were not claiming refunds to which they were entitled, he suggested that the 'quantum of tax saved could be so small that many consider it uneconomic to claim' (Irish Independent, 2006). The Irish Taxation Institute (ITI) has undertaken a number of surveys of Irish taxpayers. In 2006, the ITI reported that over 50 per cent of employee taxpayers were confused about their taxes, although 88 per cent 'were not afraid to engage with Revenue about tax' (Redmond, 2006). A further survey in 2009 reported that 35 per cent of employees depend on their employers to organise their tax affairs (Irish Taxation Institute, 2009). That report also noted that employee taxpayers in general appear to under-claim certain tax reliefs.

Section 112 of the Taxes Consolidation Act 1997 (TCA 1997) ${ }^{1}$ charges the emoluments arising from an individual holding public office or employment within the Republic of Ireland to income tax. It is assessed under Schedule E and, generally, taxes due under this schedule are paid through the Pay As You Earn (PAYE) 
system. Benefits in kind, expense allowances, ex-gratia payments and any other form of compensation payments are also assessable under Schedule E irrespective of whether paid before the commencement or after the cessation of an office or employment. Section 114 (S.114) of the TCA 1997 sets out the main rule that governs the deductibility of expenses from income chargeable under Schedule E. Judge (1995) noted that there is no deduction for expenses incurred in placing an individual in a position to perform the duties of the office or employment. Specifically, to qualify for travelling expenses deductions, the holder of the office or employment must be necessarily obliged to incur and defray the expenditure in the performance of the duties of the office or employment. More generally, allowable deductions against Schedule E income are restricted to expenses incurred wholly, exclusively and necessarily in the performance of the duties of the office or employment.

The restrictive nature of this general rule for employees' expense claims under Schedule E has resulted in taxpayers in both Ireland and the UK seeking legal interpretation and clarification of the rule from the law courts. ${ }^{2}$ Although the 1980 Commission on Taxation in the Republic of Ireland received a number of submissions that the rule is too narrow and is unfair compared with the more liberal expenses allowable in the case of self-employed persons, there has been no change to the restrictive wording of the rule since its introduction in 1853. Indeed, the first report of the 1980 Commission on Taxation on direct taxation published in July 1982 recommended that there be no change to the Schedule E expenses rule and noted that:

It is doubtful if the present inequity could be satisfactorily dealt with by bringing the expenses rule under Schedule E into line with that of Schedule D. Once expenses voluntarily undertaken by an employee in connection with his duties are allowed as a deduction from his income, it becomes very difficult to draw a clear line of distinction between such expenses and personal expenses or between expenses reasonably incurred and those not reasonably incurred. If the Schedule E expenses rule were relaxed, the result would open up new avenues of tax avoidance and give rise to inequities between one Schedule E taxpayer and another whereas the present rule achieves a high degree of equity among Schedule E taxpayers (First Report of the Commission on Taxation: Direct Taxation, July 1982, par. 10.79, p. 150).

The restrictive nature of S.114 of the TCA 1997 did not appear to be considered by the 2008 Commission on Taxation and did not feature in the report of the Commission published in 2009 and hence now seems to have general acceptance. The issue may, of course, be the subject of further interpretation and clarification by the Irish courts. Despite the rigidity of the courts' interpretation to date, Revenue has adopted a more flexible application of S.114, granting tax relief for certain categories of employees in the form of flat rate expense deductions (FRED), which are deductible from Schedule $\mathrm{E}$ income without any obligation on the part of the employee to incur those expenses.

The objectives of this study are to explore FRED, to investigate the negotiation process for the granting of these deductions and to consider the extent to which taxpayers are remiss in claiming them. The study presents the findings of web-based 
Farrelly, McCluskey and Willis

survey responses on the extent to which employees in two selected sectors are aware of their entitlements.

The remainder of the paper is structured as follows: the next section examines the Irish legal framework for employee expenses and provides a brief review of the interpretation by the courts of the phrase 'necessarily'. This is followed by an explanation of the existing non-statutory arrangements in place for the granting of FRED to various categories of employees. The survey findings are then presented and the paper concludes with recommendations and avenues for future research.

\section{THE IRISH LEGAL FRAMEWORK FOR EMPLOYEE EXPENSES}

From the introduction of income tax in Ireland in 1853 until 1 April 1922, the basis of assessment for employees (other than the holders of public offices) was Schedule D rather than Schedule E. Under the regulations, those employees who did not hold public office paid income tax based on the average income of the three preceding years. The income of the holders of public offices was liable under Schedule E on an actual basis (Dowling and Harvey, 1998). Hence, the restrictive nature of the general rule for employees' expense claims under Schedule E applied to the holders of public offices while a more liberal expenses allowable rule applied to employees assessable under Schedule D.

In 1921, the Inspector of Taxes assessed a railway clerk in Wales to income tax as an office holder under Schedule E. The taxpayer appealed and in 1922 the House of Lords confirmed that the railway clerk was not an office holder and should be assessed for income tax purposes under Schedule D (GWR Co (re Hall) v Bater). Dowling and Harvey (1998) observed that this decision in the House of Lords set a precedent for the large number of UK taxpayers who were then assessable under Schedule E and that there was a serious risk that the ruling in the case would have resulted in a substantial loss in revenue for the British Exchequer. In response, the Finance Act 1922 moved all employed persons into Schedule E. From a review of parliamentary debates on the amendment at the time there appears to have been little, if any, consideration of the effect of this on the deductibility of employee expenses, or that those employees who were not the holders of public offices were, from 1922, to be assessed to income tax on their actual income rather than their average income over the previous three years. Essentially, the employees concerned lost the advantage of the relatively generous approach to the computation of income and deductible expenses by default. The Irish Finance Act 1926 passed the relevant provisions of the UK Finance Act 1922 into Irish tax law with effect from 1 April 1922.

The restrictive nature of the general rule for employees' expense claims has resulted in taxpayers in both Ireland and the UK seeking legal interpretation and clarification of the rule from the law courts. Judge (1995) noted that in Lomax $v$ Newton, Vaisey J emphasises that the words used in the Schedule are:

... notoriously rigid, narrow and restricted in their operation ... compliance with each and every one of them is obligatory if the benefit of the Rule is to be claimed 
successfully. They are, to my mind, deceptive words in the sense that when examined they are found to come to nearly nothing at all (Judge, 1995, p. 1252).

One of the earliest cases taken on this issue was in 1926, Ricketts $v$ Colquhoun. The court held that the travelling and hotel expenses of a barrister residing and practicing in London but employed part-time as the Recorder of Portsmouth were partly incurred before entering upon such duties and partly after fulfilling the duties and were neither necessary to the office nor incurred in the performance of his duties. Judge (1995) quoted Lord Blanesburgh's opinion that:

\begin{abstract}
If an employee decides to reside away from his work, he must bear the cost of staying away from home that is by his own choice and not by reason of any necessity arising out of his employment, such expenses are disallowed by the emphatic qualification that the expenses must be 'wholly, exclusively and necessarily' so incurred (Judge, 1995, p. 1253).
\end{abstract}

The principles set down by the decision in Ricketts $v$ Colquhoun have been applied in a number of similar cases, including Cook $v$ Knott, Revell v Directors of Elworthy Bros E Co. Ltd, Andrews v Astley, Nolderv Walters, Burton v Rednall, Parikh v Sleeman, Miners $v$ Atkinson and Kirkwood $v$ Evans.

Despite the relatively rigid nature of the decision in Ricketts $v$ Colquhoun, however, travel between 'bases' or 'two places of work' may be deductible as such travel may be required 'in the performance' of the duties. For example, in Pook $v$ Owen, a general practitioner employed part-time at a nearby hospital was also required for emergency call-outs from home. The court held that travelling expenses between the doctor's home and the hospital while on call were allowable as his responsibility for the patient began as soon as he received a telephone call and hence the expenses incurred in travelling to the hospital were in the performance of his duties. This principal was followed in the Irish case of F.G. $v O^{\prime}$ Coindealbhain.

A requirement by the employer that the employee incurs certain expenses does not ensure that the expenses are deductible. The objective test of necessity obliges the taxpayer to show that that the expense is 'necessarily' imposed on the holder of the office or employment by 'the duties of that office or employment'. In Brown $v$ Bullock, a bank manager argued a club membership subscription was 'necessarily incurred' as his employer required him to become a member to foster local contacts. The Court of Appeal held that the cost was not 'necessarily incurred in the performance of his duties' as a bank manager. Donovan LJ stated:

The test is not simply whether the employer imposes the expense, but primarily whether the duties do, in the sense that irrespective of what the employer may prescribe, the duties themselves involve the particular outlay (Judge, 1995, p. 1254).

The decision in the Brown $v$ Bullock case featured in the parliamentary debates on the 1963 UK Finance Bill in the House of Commons (House of Commons, 1963). The member for Darwen argued that it was unfair that the bank manager in the case, who was obliged to attend the club, was liable to income tax on the benefit without an equivalent deduction. At the time, the Financial Secretary was resisting 
Farrelly, McCluskey and Willis

a proposed amendment to the Finance Bill that school teachers be given tax relief in respect of expenditure on refresher courses which they were necessarily obliged to incur to maintain teaching competence. The Shadow Financial Secretary to the Treasury put forward the following new clause, no. 20: 'Income Tax, Schedule E: Deduction of Obligatory Educational Expenses':

If the holder of an office or employment of profit is obliged as a condition of holding the same to engage in certain studies or to receive certain tuition or examination, any expenses necessarily incurred by him in carrying out such studies or in procuring such tuition or examination shall be deemed to be incurred wholly, exclusively and necessarily in the performance of the duties of the office or employment, to be defrayed out of the emoluments thereof and accordingly to be deductible from the emoluments to be assessed (Shadow Financial Secretary to the Treasury, House of Commons, 1963).

The Financial Secretary to the Treasury rejected the proposed amendment and asserted:

... it would be impossible to defend giving tax relief to an employee for training that he was required to undertake by one employer while equally refusing it to an employee doing comparable work in another firm that voluntarily took that same training course, ... even though it may appear unfair, ... any general change in the Schedule E expense rule which replaced an employer's requirement to the statutory test would be indefensible ... it would then be open to all forms of abuse, where employees could seek to obtain tax relief for various types of expenditure (Financial Secretary to the Treasury, House of Commons, 1963).

The issue of allowing tax relief in respect of expenditure on training courses was re-examined in two recent cases, both of which relied on the decision in Brown $v$ Bullock. In DW Perrin v UK Special Commissioners, Mr Perrin was a trainee accountant whose contract of employment obliged him to study for professional accountancy examinations at two nominated external accountancy educational providers, subject to a penalty of dismissal if he did not attend. The contract required that $\mathrm{Mr}$ Perrin's employers provide relevant training and study leave to enable him to qualify as a chartered certified accountant. Mr Perrin was contractually obliged to pay for the tuition and exam fees and these were not subject to reimbursement. The UK Special Commissioners disallowed the training costs on the basis of the established precedent that costs incurred by an employee to enable him/her to perform his/ her duties rather than incurred in the actual performance of his/her duties were not allowable. The fact that the contract of employment required Mr Perrin to incur the expenditure was not sufficient because he did not incur the training costs in the actual performance of his duties at the firm. Carr (2008) observed that because the question of whether or not the training costs were deductible was a mixed question of law and fact, the Special Commissioner's decision is not final and ultimately may come before the courts.

The second case, HMRC $v$ Banerjee, which was decided in the UK High Court, concerned whether expenses incurred by a doctor in attending training courses were allowable against her employment income. Mitchell (2009) noted that what 
Is 'Necessarily' Really Necessary?

was critically important in this case was the finding of fact by the General Commissioners that:

Dr. Banerjee's employment as a specialist registrar constituted part of her five-year training programme. The post was essentially a training post and the courses that Dr. Banerjee attended formed a mandatory and essential part of her training. The service commitment of seeing patients was, of course, another part of her training, but it was not the only part. Her attendance at the courses took place during working hours, and was part of the job that she was paid to do (quoted in Mitchell, 2009, p. 12).

In a commentary on the case, Mitchell (2009) observed that the decision in the case does not broaden the criteria to claim expenses deductions but shows that each case must be considered on its own merits and that the entitlement to a tax relief must be considered by reference to the duties of each particular employment.

\title{
FLAT RATE EXPENSES
}

\section{Background}

Despite the strict judicial interpretation of S.114, the practice developed in both Irish and UK jurisdictions of negotiating and agreeing FRED for various categories of employees. These are defined by the Irish Revenue as:

\begin{abstract}
... expenses that are incurred in the performance of the duties of the employment and are directly related to the 'nature of the employee's employment'. A standard flat rate expenses allowance (deduction) is set for various classes of employee (Office of the Revenue Commissioners, 2010a).
\end{abstract}

It is not possible to identify when the practice started. An official within the Office of the Revenue Commissioners, involved in negotiating such deductions, could not confirm exactly when relief for flat rate expenses was first introduced but believed it pre-dated the Income Tax Act of $1967 .{ }^{3}$ Dáil debates from 1963 corroborate this with a number of questions posed to the Minister for Finance on the issue during that year (Dáil Éireann, 1963a, 1963b). Despite this long-standing practice of granting FRED they have never been formally legislated for. Over time there has been a consistency in the rationale given for the existence of these allowances. In 1963 the then Minister for Finance stated that FRED 'are given as a matter of administrative convenience as representing a round figure estimate of the deduction for expenses to which the employees concerned would be entitled' (Dáil Éireann, 1963a). A similar rationale was given in 2002 by the Minister for Finance who stated they 'avoid the necessity for each individual to make a separate claim' (Dáil Éireann, 2002). An additional reason given by a Revenue official who negotiates deductions is that it 'ensures uniformity of approach in Revenue offices around the country'. ${ }^{4}$

As of 2010, FRED have been agreed for 163 categories and subcategories of employment and a list outlining the occupations and deductions available may be accessed online (Office of the Revenue Commissioners, 2010b). The amounts range from just $€ 21$ for kitchen porters to $€ 2,476$ for members of the RTE Symphony and 
Farrelly, McCluskey and Willis

Concert Orchestras. The average is $€ 249$ and the mode is $€ 318$. Relief is available at the taxpayer's marginal rate of tax and it is granted without any requirement on behalf of the individual taxpayer to actually incur the expenditure.

Estimated costs in terms of revenue forgone for all personal tax credits, reliefs and deductions are published by Revenue but it accepts that the estimates shown in many cases are tentative (Office of the Revenue Commissioners, 2009a, p. 16). The estimate for FRED for 2006, the most recent year available, shows a cost to the exchequer of $€ 71.2$ million in respect of claims by 960,400 taxpayers. However, this estimate is subject to a number of limitations, the most significant of which is that an adjustment is included in the cost figures to compensate for incomplete numbers of tax returns. Less than 5 per cent of all PAYE taxpayers completed a tax return in 2006 (Joint Committee on Finance and the Public Service, 2007, p. 56). Consequently, this appears to be a particularly tentative estimate. This may explain the wildly fluctuating variations in the cost reported year on year with, for example, a cost of $€ 153.8$ million estimated for 2002 (Office of the Revenue Commissioners, 2006). Nonetheless, it may be concluded that a significant number of taxpayers qualify for an allowance, albeit is not clear how many actually receive or claim it. The most recent Commission on Taxation established a comprehensive list of all tax relieving measures in the Irish taxation system, identifying those measures that are structural reliefs and hence part of the benchmark tax system and those that are tax expenditures (Commission on Taxation, 2009, p. 237). Costs were provided for all tax expenditures together with recommendations regarding their continuance or otherwise. Surprisingly, FRED were not discussed under either heading and only a passing reference to employee expenses is to be found within the Commission's report. Given the non-statutory nature of FRED, and the significant differences in the amount of relief granted to different categories of employees, the following sections of the paper seek to explore how they are agreed and communicated to taxpayers.

\section{Negotiation Procedure}

'The amount of the deduction is agreed between Revenue and representatives of groups or classes of employees' (Office of the Revenue Commissioners, 2010a), usually trade unions. They are 'reviewed periodically on receipt of a claim by that body to reflect changes in costs, conditions of work, etc.' (Dáil Éireann, 2002, p. 141). Revenue was not in a position to provide information on the expenses included in claims as, in its view, 'details of agreements reached between Revenue and representative bodies/unions are strictly confidential'. ${ }^{5} \mathrm{~A}$ trade union official provided access to his correspondence files with the Office of the Revenue Commissioners and his union members from 1996 to 2009 for a number of categories of employees. This enabled a review of one representative body's negotiation process and it is reasonable to conclude that a similar procedure applies for other bodies. The process commences with an approach from the union requesting an allowance. Following consideration by a Revenue official, an 'offer' is made by the appropriate individual within Revenue to which the union official's agreement is sought. Generally, the union response is to propose a higher amount, sometimes informally by phone. A revised offer is typically made, often with the caveat that the allowances 
will not be reviewed for a period of at least three years and the union is asked for written acceptance of the offer. Further conditions may be included as part of the agreement. For the occupations included in the files reviewed, there is frequently a stipulation that the employees are obliged to wear a uniform. The amount of the associated allowance varies depending on who is responsible for providing and laundering the uniform. However, there is also an allowance available for employees in situations where the employer both supplies and launders the uniform and it is not clear what expense, if any, this relates to. The union then notifies its members of the agreement and frequently provides the file reference number for members to use in any dealings with the Inspector of Taxes.

The process for the revision of an existing allowance takes a similar path with the union initiating the negotiation process at the end of the prescribed period. The offer from Revenue is typically to increase the allowance in line with the consumer price index, again for a defined period. On occasion, adjustments are sought by the union to achieve parity with other similar occupations. Variations in the requirements of different Revenue officials may be observed from the union files. Some officials refer to the provisions of S.114 while others seem more willing to avail of the flexibility provided under the care and management provisions of S.849 TCA 1997 and make no reference to the requirement that the expenses be necessarily incurred in the performance of the duties of the employment as stipulated in S.114. Details of actual expenses incurred are frequently requested when negotiating new claims and also occasionally sought when reviewing existing allowances. In respect of one category of employee, in addition to details of actual expenditure incurred, a comprehensive breakdown of the functions carried out by the employees is also requested.

The manner in which FRED are negotiated, agreed and publicised is likely to contribute to the inconsistencies that exist among the various categories of employees. No regular review of the level of individual FRED available appears to be undertaken by Revenue. Instead revisions seem to be prompted by a request from employee representatives. The FRED available to some categories of employees (for example, plasterers, electricians and shipping officers) have not increased in over seventeen years (Office of the Revenue Commissioners, 1993-2009). In contrast, other categories of employees have been reviewed regularly. Over the same seventeen-year period there have been six increases in the allowances available for teachers and third-level academic staff. This inconsistency regarding review exists even among occupations where similar expense outlays would be expected. There has been no increase in the allowances granted to any of the ten occupations within the hotel industry since 1993 while domestic staff in hospitals have received five increases since then. Local authority engineers have not received an increase since 1995 while engineers employed by the civil service have received three, albeit small, increases. Up until 1995 there was a gender difference in the deductions available for nurses, with females receiving twice that of males. While this anomaly was removed for nurses it still exists for cardiac technicians. A Revenue official was unable to explain this anomaly but suggested that when the allowance was agreed it would have been granted by virtue of gender-specific expenditure incurred. ${ }^{6}$ The reason put forward for the difference in allowance between full- and part-time 
Farrelly, McCluskey and Willis

firefighters is that the expenditure incurred by full-time firefighters is greater than for part-time staff. ${ }^{7}$ However, the allowances granted contradict this as the allowance granted to part-time firefighters is 50 per cent higher than that granted to their full-time colleagues. There are also incidences of FRED being granted to employees whose occupation is not included on this list.

\section{Information Sources}

Huerta and d'Entremont $(2007$, p. 97$)$ suggest that there may be a failure to claim tax deductions 'without well-crafted outreach strategies'. Given the extra statutory concessionary nature of FRED, information has traditionally been difficult for taxpayers to access. Historically, there appears to have been a policy to publicise the reliefs as little as possible. In reply to a question asked in the Dáil in April 1963, the Minister for Finance stated that 'since these allowances involve an element of confidentiality I do not propose to publish them'. He went on to describe the rationale for the allowances and their agreement with representatives of employees and that 'it may be taken that the individual workers are aware of the position' (Dáil Éireann, 1963a). In July that year questions were asked in the Dáil about recommendations contained in the 1962 report of the Commission of Income Tax regarding greater publicity for these allowances. When questioned as to whether he would arrange for the allowances to be publicised in the annual report of the Revenue Commissioners or some other suitable format, the Minister of Finance replied that he would 'have to consider that'. On then being asked whether he considered them as confidential he responded, 'not exactly, but we do not want to encourage people too much' (Dáil Éireann, 1963b).

The agreed list is published annually in Tax Briefing, a publication published by the Revenue Commissioners since 1990. However, this is a publication circulated to tax practitioners and historically not easily accessible to Schedule E taxpayers. While the list has been available on the Revenue website for some time, until recently it was not very visible and was difficult to find, even for those who were aware of its existence. The Joint Committee on Finance and the Public Service (Joint Committee) investigated under-claiming of allowances by taxpayers in 2007 and concluded that FRED 'were poorly advertised by Revenue' (Joint Committee on Finance and the Public Service, 2007, p. 15). They recommended that these allowances 'should be advertised more widely by Revenue and should be given greater prominence on the Revenue website and other media' (Joint Committee on Finance and the Public Service, 2007, p. 19). This recommendation was adopted and they are now included under the employee expenses heading on the PAYE section of the Revenue website with links from a number of related topics and from the PAYE Anytime system.

The current version of the employee tax return (Form 12) includes a section on allowable deductions incurred in employment under the general heading of 'claim for tax credits, allowances and reliefs'. Employees are asked for the nature of their employment and the amount of their expenses with no explanation provided or conditions set out. If employees are unaware of the existence of FRED they are unlikely to complete this section of the return. As there has been no requirement since 2005 to state occupation elsewhere on the return, Revenue is not prompted to grant the allowance unless the taxpayer has completed this section. Consequently, 
it is quite possible that even those employees who submit a tax return are not receiving the deduction they are eligible for. Prior to 2003, Form 12 requested particulars of 'expenses wholly, exclusively and necessarily incurred in the performance of the duties of the employment', with details to be set out on a separate sheet. Between 1996/1997 and 2002, a statement was included that 'if approved "flat rate" expenses apply you need not complete this section' which suggested that FRED were applied automatically but it was dependent on the employee giving an appropriate description of their employment. There is no statutory requirement on those whose only source of income is employment income to submit a Form 12 annually. In 2006, less than 5 per cent of all PAYE taxpayers completed a Form 12 (Joint Committee on Finance and the Public Service, 2007, p. 56). Consequently, the majority of taxpayers who are claiming FRED are doing so by other means. Claims for tax credits and allowances can be made through PAYE Anytime, through LoCall, by writing to the local Revenue office or by calling to the local office. These methods of claiming and/or adjusting allowances and reliefs are straightforward and less formal than submitting a full tax return but they all require the taxpayer to be proactive in claiming the allowance and to be aware that it is available in the first instance. The current online system, PAYE Anytime, lists FRED with other tax credits, includes a link to the information on the website and uses a drop-down menu to identify occupation. Hence those who access PAYE Anytime to claim other personal reliefs may be prompted to explore and claim FRED.

The principal means of communication between Revenue and taxpayers is their tax credit certificate (Joint Committee on Finance and the Public Service, 2007, p. 18), which is accompanied by a short leaflet explaining all the standard credits that are available. According to the presentation made by the Revenue Commissioners to the Joint Committee, taxpayers are encouraged to check the credits given against those available and advertisements are placed in the papers and on radio telling people about this (Joint Committee on Finance and the Public Service, 2007, p. 58). Prior to the publication of the Joint Committee's report in 2007, no reference was made to FRED in these annual leaflets. An information leaflet announcing the new online self-service facility for PAYE taxpayers was sent to employees in summer 2006. Flat rate expenses credit was listed as one of eight credits which could be claimed on the limited internet service. It was similarly included on the self-service options on the 2007 information leaflet as a credit which could be claimed online. However, it was not included on the list of tax credits on the face of the leaflet. The Joint Committee were critical of the language used in information leaflets and claim forms by Revenue and recommended that a systematic review be undertaken of all information leaflets and claim forms to address the design, complexity and language of the documents (Joint Committee on Finance and the Public Service, 2007, p. 18). Following these recommendations, the 2008 information leaflet was completely redesigned in a cartoon format and it encouraged taxpayers to claim their full entitlements. Work-related expenses were listed as one of the most common tax credits and inside the leaflet taxpayers were told 'don't forget, your job could entitle you to some expenses ...' (Office of the Revenue Commissioners, 2008). The less formal style of leaflet was maintained for 2009 with uniforms given as an example of work-related expenses. The language used was very user friendly and the word 
Farrelly, McCluskey and Willis

'necessarily' was not used in any of these redesigned communications. Because there were no changes to PAYE in the 2010 Budget, tax credit certificates and consequently information leaflets were not forwarded to employees in 2010 (Office of the Revenue Commissioners, 2010c).

\section{Taxpayer Education}

In recent years the issue of taxpayers under-claiming their entitlements has entered the political agenda. The Minister for Finance in his 2006 budget speech said that the Government was 'determined to make it easier for ordinary taxpayers to claim and receive their rightful entitlements' (Dáil Éireann, 2006a). The Joint Committee addressed the issue in 2007 and in their report acknowledged that the Revenue Commissioners are proficient as tax collectors but that they have an equal duty to demonstrate the same proficiency to people who overpay tax and that they must educate taxpayers about their tax entitlements (Joint Committee on Finance and the Public Service, 2007, pp. 11-12). This responsibility to help taxpayers receive their due entitlements is recognised by Revenue (Office of the Revenue Commissioners, 2009 b, p. 32, 2010d, p. 37). While there is an acknowledgment by the tax authorities that tax is overpaid by some, no reliable estimates for the amount overpaid by employees exist. The chairman of the Revenue Commissioners estimates that it could be $€ 100$ million per annum (Dáil Éireann, 2006b), while the ITI estimate that the tax overpaid due to not claiming medical expenses relief alone could be as much as $€ 50$ million per annum (Joint Committee on Finance and the Public Service, 2007, p. 46).

The ITI has undertaken a number of initiatives to educate the public regarding their obligations and entitlements. These include publicity campaigns and tax guides written for the ordinary taxpayer in a range of languages. They commissioned research in 2006 which showed that only 58 per cent of PAYE taxpayers understood the tax system and 43 per cent were unsure whether they were getting all their entitlements (Irish Taxation Institute, 2009). They found that significant numbers were not claiming specified named reliefs, for example, 50 per cent of taxpayers were not claiming tax relief on medical expenses (Redmond, 2006). Following the publication of these findings, in summer 2006 Revenue launched a campaign to educate taxpayers regarding their entitlements (Office of the Revenue Commissioners, 2007a, p. 4). The latter end of 2006 saw a 280 per cent increase in the number of taxpayers seeking balancing statements compared to the same period the previous year (Office of the Revenue Commissioners, 2007b). Revenue continued this campaign in each of the following years, engaging in advertising, promotion of the PAYE Anytime website, direct marketing, a public relations drive, information posters, attendance at trade union conferences and visits to employer premises (Office of the Revenue Commissioners, 2010d, p. 37). In 2007, 783,933 refunds were made to employees totalling $€ 525,797,535$, which was a 26 per cent increase on the previous year. 2008 saw a further 10 per cent increase in refunds. ${ }^{8}$ This indicates a measure of success in the information campaigns of the Revenue and ITI. These campaigns have emphasised certain reliefs, with much attention focused on medical expenses and related credits. In 2008, an online video was produced showing taxpayers how to claim relief for medical expenses and posters and leaflets were distributed to doctors' 
surgeries and pharmacies (Office of the Revenue Commissioners, 2009b, p. 32). In contrast, little attention has been paid to FRED by either the Revenue or the ITI. Neither the information guides published by the ITI nor the publicly accessible areas of their website make any reference to the possibility of this relief.

In 2009, the ITI commissioned another survey on consumer attitudes towards tax issues. Some improvements were found compared to 2006, with 63 per cent of respondents claiming they understood the PAYE system and 59 per cent believing they were claiming all the reliefs they were entitled to. However, despite the publicity campaigns once again significant numbers of taxpayers were found not to be claiming certain reliefs (Irish Taxation Institute, 2009). The reasons why taxpayers do not claim their entitlements was not explored. Recent Revenue annual reports state that it aims to make it easier for customers to claim their entitlements (Office of the Revenue Commissioners, 2009b, p. 32, 2010d, p. 37) and indeed 60 per cent of respondents to the 2009 ITI survey believe that the process of claiming reliefs is now easier (Irish Taxation Institute, 2009). Revenue believes that to achieve this objective it must develop more imaginative ways of interacting with customers, such as granting reliefs automatically and prompting claims on the basis of information already available to them (Office of the Revenue Commissioners, 2009b, p. 32, 2010c, p. 37). Its treatment of FRED conflicts with this as it is left to the trade union movement to notify members of any changes to their entitlements. When queried, Revenue confirmed that tax credit certificates are not automatically updated whenever FRED are renegotiated. Instead, the 'representative body or union generally informs its members and the customer can then claim relief by using any of the various services offered by Revenue'. ${ }^{9}$ It is not clear how non-union members are expected to be informed of the relief.

\section{DATA COLLECTION}

To explore taxpayers' knowledge of FRED and other tax reliefs, a questionnaire was developed and circulated to two groups of taxpayers. University lecturers and local authority engineers and firefighters were chosen for the study as both groups are entitled to FRED and have publicly available e-mail addresses. A web-based survey was chosen in preference to a postal survey as it facilitates the distribution of surveys in a time-saving and cost-efficient manner and participants can conveniently respond. E-mail addresses of 606 academic staff in a range of institutions and departments were randomly selected from university websites. Ten local authorities circulated the e-mail internally to their engineers and firefighters while additional e-mail addresses were chosen randomly from relevant local authority websites, resulting in a total sample for this group of 600. Customised e-mails were sent to both groups inviting them to participate in the web-based survey. They were assured the survey was anonymous and that the data would only be used for the purposes of this research study. The survey was hosted by SurveyMonkey.com, which supports the distribution of reminder e-mails to non-respondents. Three reminders were sent to non-respondents at intervals of three weeks. Thirty-six e-mails were returned as undelivered and a further twenty-four individuals were 
Farrelly, McCluskey and Willis

omitted as they were on maternity or sabbatical leave or were visiting non-Irish tax resident persons. Thirty-one respondents replied that they did not wish to partake in the survey and a further six were omitted due to incomplete responses. Completed questionnaires were received from 557 respondents: 314 engineers/firefighters (a response rate of 54.8 per cent) and 243 university lecturers (a response rate of 42.4 per cent). The resulting overall usable response rate of 48.6 per cent is considered acceptable for surveys of this nature.

\section{FINDINGS}

Respondents were asked to classify their knowledge of FRED using a five-point Likert scale ranging from excellent to very poor. A majority of respondents, 63 per cent, indicated their knowledge is either poor or very poor while only 13 per cent stated that their knowledge is either good or excellent. As an introduction to the next section of the questionnaire, respondents were informed that workers in certain occupations can claim a flat rate tax allowance for work-related expenses such as tools or special clothing and an example was given relevant to the occupation of the particular respondent. Their responses to the remaining questions in this section confirmed their lack of awareness of the allowance.

Despite all respondents being engaged in occupations which qualify for FRED, 57 per cent indicated that they are unsure whether they qualify for an allowance and only one-third of respondents stated that they actually claim it. Those who do not claim the deduction were asked to give reasons why this was the case. They were presented with three possible reasons and asked to identify which, if any, applied to them and to give any other reason for their failure to claim the allowance. As illustrated in Table 1, the majority of those who do not claim FRED indicated that there are multiple reasons why, with two-thirds or more specifying they are not aware they can claim, do not know how to or have not received any information regarding claiming.

TABLE I: REASONS FOR NOT CLAIMING FLAT RATE TAX ALLOWANCE

\begin{tabular}{ll}
\hline I wasn't aware I could claim & $79 \%$ \\
I don't know how to claim & $65 \%$ \\
I haven't received any information & $75 \%$ \\
\hline
\end{tabular}

Alternative reasons were given by just twenty respondents, who indicated that either they do not have the time or the inclination to fill in forms or they do not incur work-related expenses so think the allowance is not available to them. Among those who know that they qualify for the allowance, 29 per cent do not realise that the onus is on them to make a claim and only 30 per cent know that the amount of the allowance occasionally increases.

While the focus of the study is not on differences between the two groups of respondents, it is interesting to note that differences are present. Exactly half of 
engineers are unsure whether they qualify for an allowance or not, while this increases to 66 per cent for academics. A Pearson chi-square test showed the difference between both groups to be significant $(p<0.0005)$. This may indicate that the professional organisations or unions representing the local authorities take a more active role in notifying their membership of their entitlements or that a greater proportion of respondents within this group are union members. Additionally, the difference could also be due to the more disparate nature of the respondents in the university category, who were spread across a range of departments and faculties. For those who claim the allowance there are no differences between the two groups of respondents as to whether they are aware that the onus is on them to make the claim $(p<0.777)$ or that it occasionally increases $(p<0.128)$.

As discussed earlier, Revenue and the ITI have engaged in campaigns to educate the public about their entitlements to certain tax reliefs with much of the focus directed on medical expenses. Due to the nature of medial expenses it is necessary to claim this relief after the year end and it requires taxpayers to be proactive in claiming it. Consequently, as part of the current study data were collected on respondents' medical expense relief claims. A significant majority of respondents, 87 per cent, stated that they had incurred medical or dental expenses within the previous four years. ${ }^{10}$ Only 59 per cent of these had claimed tax relief. This is similar to the findings of the ITI survey, which reported that 53 per cent of respondents claim relief on medical expenses (Irish Taxation Institute, 2009). The current research project asked those who do not claim the relief to indicate why. Three reasons were included on the questionnaire (see Table 2) and respondents were asked to specify any other applicable reason.

TABLE 2: REASONS FOR NOT CLAIMING MEDICAL EXPENSES RELIEF

\begin{tabular}{ll}
\hline I wasn't aware I could claim & $19 \%$ \\
I don't know how to claim & $24 \%$ \\
I haven't held on to receipts & $21 \%$ \\
\hline
\end{tabular}

Unlike FRED, lack of awareness of the relief is not responsible for failure to claim medical expenses relief. Only 19 per cent of those who had incurred medical expenditure but not claimed tax relief are unaware of their entitlements and only 24 per cent do not know how to claim. Forty-eight respondents specified other reasons for not claiming, which break down into three broad issues. The most common reason $(n=21)$ is that the respondents are too busy or have not got around to it. Fifteen respondents are confused regarding their entitlement to tax relief, believing it to be connected to their PRSI class or, alternatively, not available to them as their expenses were incurred overseas. The remaining twelve erroneously think that the expenses incurred must exceed a certain amount before relief is available. While there is still some degree of confusion regarding tax relief for medical expenses, respondents were better informed of their entitlements to this relief than to FRED, suggesting that an information campaign can be effective in educating taxpayers regarding their entitlements. 
Farrelly, McCluskey and Willis

\section{CONCLUSIONS AND RECOMMENDATIONS}

This paper explores the courts' strict interpretation of S.114, which grants relief for work-related expenses and sets out the extra statutory concession arrangements which Revenue has in place to facilitate the application of S.114, i.e. FRED. While efforts have been made by Revenue and the ITI to inform taxpayers of their general entitlements to tax reliefs, the data collected in this study show that taxpayers remain ill-informed and confused by FRED. Consequently, the paper concludes with a number of recommendations to revise and update current practice.

It is recommended that a review of the legislation regarding employee expenses, which has been on the statute books since the introduction of income tax in Ireland in 1853, is long overdue. The rationale and equity in a distinction between expense deductions for the self-employed and employees should be explored and debated.

The current negotiation process to agree FRED introduces inequities with respect to expense deductions. There is an absence of transparency with regards to the negotiation process and the present unsatisfactory system, which is dependent on employee representatives initiating claims for FRED, should be replaced with a more regularised system. A full review of the list of allowances currently agreed should be undertaken with all anomalies removed and particular attention paid to those occupations which have not been reviewed for many years. Thereafter, these allowances should be subject to the same degree of scrutiny and review as other tax credits and given the same degree of visibility.

This study has found that significant numbers of taxpayers are not claiming their entitlements, particularly with regard to FRED, mainly due to lack of knowledge. Recent years have seen a move to granting tax relief at source where possible. Indeed the Joint Committee have called for the extension of this method of relief (Joint Committee on Finance and the Public Service, 2007). Since 2004, employers are responsible for the application of the valuation rules for the taxation of employee benefits. A similar obligation regarding employee expenses should be considered. Employers should be required to deduct FRED when arriving at taxable pay as they are currently required to do for pension and permanent health benefit premiums. Such arrangements are currently in place for comparable flat rate expenses in the UK. If this is deemed unacceptable, an alternative would be to amend the end of year return of details of employees' pay and tax deducted (P35) to include details of the employees' occupation. The Inspector of Taxes could then ensure that the relief is included on the employees' tax credit certificates. Either of these recommendations would negate the necessity for taxpayers to actively claim the relief or indeed to be aware of their entitlement to it. When increases are negotiated they should be automatically granted to relevant employees in the same manner in which increases in tax credits are applied. While acknowledging that increased efforts have been made in recent years to publicise the existence of FRED, more is required. If the recommendations above are not adopted greater effort must be made to educate employees as to their entitlements to this relief and encourage them to claim it.

This research is consistent with and contributes to the international literature on why taxpayers are remiss in claiming reliefs. However, further research is needed to explore why taxpayers who are aware of allowances and reliefs still fail to claim 
their entitlements. In particular, the failure and possible reluctance of taxpayers to claim their full entitlements could be contrasted with citizens' willingness to engage with the social welfare system.

\section{ENDNOTES}

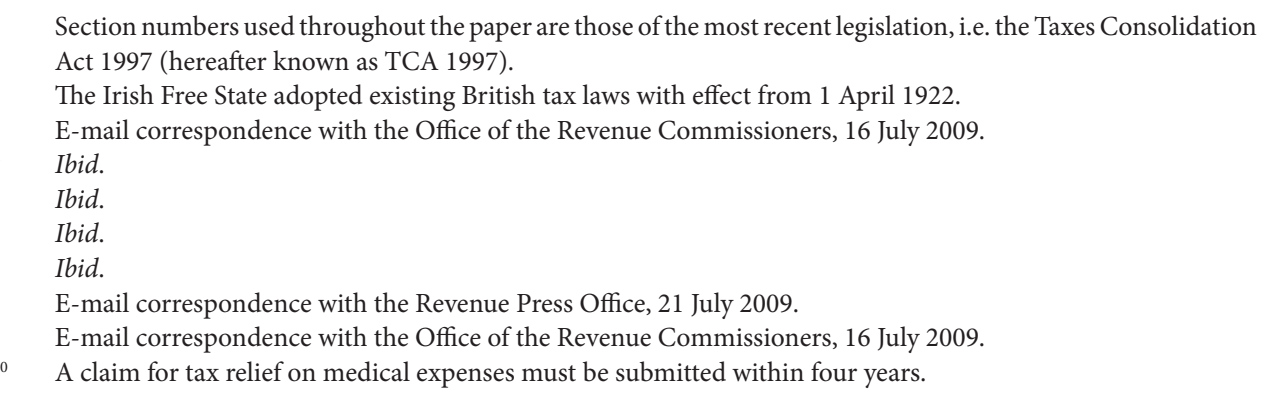

\section{TABLE OF CASES}

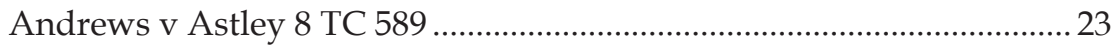

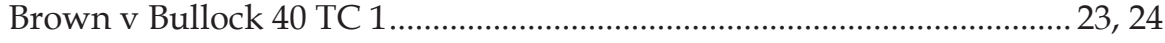

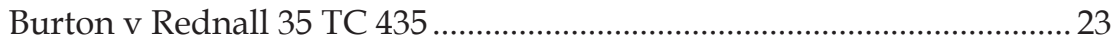

Cook v Knott 2 TC 246 ..................................................................................... 23

DW Perrin v UK Special Commissioners 2008 UK SPC spc00671 .......... 24

F.G. v O'Coindealbhain ITR 1985 ............................................................... 23

GWR Co (re Hall) v Bater 8TC 231 ............................................................... 22

HMRC v Banerjee 2009 EWHC 62CH........................................................ 24

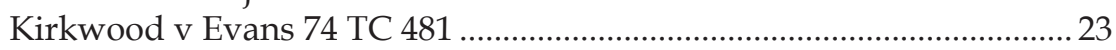

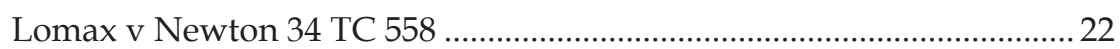

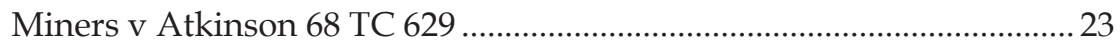

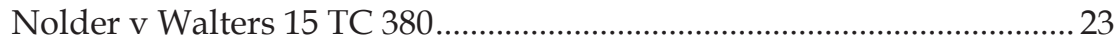

Pook v Owen 45 TC 571 ............................................................................ 23

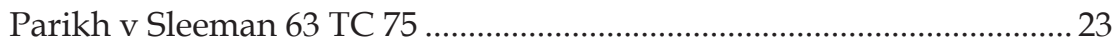

Revell v Directors of Elworthy Bros \& Co. Ltd 3 TC 12 ........................... 23

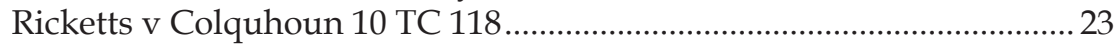

\section{REFERENCES}

Blank, R. and Ruggles, P. (1994). Short Term Recidivism among Public Assistance Recipients, American Economic Review, Vol. 84, No.2, pp. 49-53.

Blank, R. and Ruggles, P. (1996). When Do Women Use Aid to Families with Dependent Children and Food Stamps? The Dynamics of Eligibility versus Participation, Journal of Human Resources, Vol. 31, No. 1, pp. 59-89.

Carr, F. (2008). Tax Cases, Irish Tax Review, Vol. 21, No. 5, pp. 20-32. 
Farrelly, McCluskey and Willis

Chetty, R. and Saez, E. (2009). Teaching the Tax Code: Earnings Responses to an Experiment with EITC Recipients, April 2009, National Bureau of Economic Research working paper no. 14836.

Choi, J.J., Laibson, D., Madrian, B.C. and Metrick, A. (2003). Optimal Defaults, American Economic Review, Vol. 93, No. 2, pp. 180-185.

Commission on Taxation (1982). First Report of the Commission on Taxation: Direct Taxation, July 1982, Dublin: Stationery Office.

Commission on Taxation (2009). Commission on Taxation Report 2009, Dublin: Stationery Office.

Cummings, R.G., Martinez-Vazquez, J., McKee, M. and Torgler, B. (2006). Effects of Tax Morale on Tax Compliance: Experimental and Survey Evidence, Berkeley Programme in Law and Economics, working paper series no. 12, University of California, Berkley.

Dáil Éireann (1963a). Parliamentary Debates, Written Answers, Vol. 202, question 122, 23 April.

Dáil Éireann (1963b). Parliamentary Debates, Question Time, Vol. 204, questions 2-4, 9 July.

Dáil Éireann (2002). Parliamentary Debates, Question Time, Vol. 548, question 178, 19 February.

Dáil Éireann (2006a). Budget Statement 2006, Vol. 629, 6 December, available from <http:/ / debates.oireachtas.ie/dail/2006/12/06/00017.asp>, accessed 28 July 2011.

Dáil Éireann (2006b). Parliamentary Debates, Committee of Public Accounts: 2005 Annual Report of the Comptroller and Auditor General and Appropriation Accounts, 9 November.

de Bartolome, C. (1995). Which Tax Rate Do People Use: Average or Marginal?, Journal of Public Economics, Vol. 56, No. 1, pp. 79-96.

Department of Work and Pensions (UK) (2008). Income-Related Benefits Estimates of Take Up in 2007-2008, London: Crown Office.

Dowling, C. and Harvey, A. (1998). Private Sector Employees: The Necessarily Provision, Irish Tax Review, Vol. 11, No. 3, pp. 47-49.

Fortin, B., Lacroix, G. and Villeval, M. (2007). Tax Evasion and Social Interactions, Journal of Public Economics, Vol. 91, No. 11, pp. 2089-2112.

Giannarelli, L. and Clark, S. (1992). Changes in AFDC Eligibility and Participation Rates, 1981-1990, paper presented at the Association for Public Policy Analysis and Management Annual Meeting, October.

Government of Britain (1922). Finance Act, Section 18, London: Crown Office.

Government of Ireland (1997). Taxes Consolidation Act, Dublin: Stationery Office.

Government of the Irish Free State (1926). Finance Act, Section 40, Dublin: Stationery Office.

House of Commons (1963). Parliamentary Debates, Vol. 678, cc 1585-1612, 30 May

Huerta, L.A. and d'Entremont, C. (2007). Education Tax Credits in a Post-Zelman Era: Legal, Political, and Policy Alternatives to Vouchers?, Educational Policy, Vol. 21, No. 1, pp. 73-109.

Irish Independent (2006). Elderly Not Claiming Due DIRT Refunds, Irish Independent, 6 February.

Irish Taxation Institute (2009). Consumer Attitudes towards Tax Issues: redC Poll, Dublin: Irish Taxation Institute.

Joint Committee on Finance and the Public Service (2007). Interim Report on Under-Claiming of Tax Credits, Allowances and Reliefs by Taxpayers, eighth report of the Joint Committee, Dublin: Stationery Office.

Judge, N.E. (1995). Irish Income Tax, Dublin: Butterworths.

Kim, C.K., Evans III, J.H. and Moser, D.V. (2005). Economic and Equity Effects on Tax Reporting Decisions, Accounting Organisations and Society, Vol. 30, Nos. 7-8, pp. 609-625.

Krause, K. (2000). Tax Complexity: Problem or Opportunity, Public Finance Review, Vol. 28, No. 5, pp. 32-54.

Madrian, B. and Shea, D. (2001). The Power of Suggestion: Inertia in 401(k) Participation and Savings Behaviour, Quarterly Journal of Economics, Vol. 116, No. 4, pp. 1149-1187. 
Is 'Necessarily' Really Necessary?

Mitchell, F. (2009). Court Cases, ITI Tax Relay, second edition, Dublin: Irish Taxation Institute Membership Services.

Office of the Revenue Commissioners (1993-2009). Tax Briefing, Issues 10-83, Dublin: Office of the Chief Inspector of Taxes.

Office of the Revenue Commissioners (2006). Statistical Report 2005, Dublin: Stationery Office. Office of the Revenue Commissioners (2007a). Annual Report 2006, Dublin: Stationery Office.

Office of the Revenue Commissioners (2007b). Revenue Response to Finance Committee Report, Revenue.ie, available from: <http://www.revenue.ie/en/press/archive/2007/ pr_110407.html>, accessed 26 April 2010.

Office of the Revenue Commissioners (2008). Wake Up to Tax Credits, Dublin: Office of the Revenue Commissioners.

Office of the Revenue Commissioners (2009a). Statistical Report 2008, Dublin: Stationery Office.

Office of the Revenue Commissioners (2009b). Annual Report 2008, Dublin: Stationery Office.

Office of the Revenue Commissioners (2010a). Flat Rate (Employment) Expenses, Revenue.ie, available from <http://www.revenue.ie/en/tax/it/employee-expenses.html>, accessed 29 March 2010.

Office of the Revenue Commissioners (2010b). Flat Rate Expenses List, Revenue.ie, available from: <http://www.revenue.ie/en/tax/it/leaflets/flat-rate-expenses.xls>, accessed 29 March 2010.

Office of the Revenue Commissioners (2010c). PAYE Anytime Using your Mobile Phone, Revenue.ie, available from: <http://www.revenue.ie/en/online/paye-anytime-usingyour-mobile-phone.html>, accessed 15 December 2010.

Office of the Revenue Commissioners (2010d). Annual Report 2009, Dublin: Stationery Office.

Ramsden, G. and Donnay, P. (2001). The Impact of Minnesota's Political Contribution Refund Program on Small Donor Behaviour in State House Races, State and Local Government Review, Vol. 33, No. 1, pp. 33-41.

Redmond, M. (2006). Most PAYE Workers Confused by Tax System, Sunday Business Post, 25 June.

Richardson, G. (2005). An Exploratory Cross-Cultural Study of Tax Fairness Perceptions and Tax Compliance Behaviour in Australia and Hong Kong, International Tax Journal, Vol. 31, No. 1, pp. 11-67.

Richardson, G. (2006). The Impact of Tax Fairness Dimensions on Tax Compliance Behaviour in an Asian Jurisdiction: The Case of Hong Kong, International Tax Journal, Vol. 32, No. 1, pp. 29-42.

Ruggles, P. and Michel, R. (1987). Participation Rates in the Aid to Families with Dependent Children Program: Trends for 1976-1984, Urban Institute Report to Department of Health and Human Services, Washington DC: Urban Institute.

Saez, E. (2010). Do Tax Filers Bunch at Kink Points? Evidence, Elasticity Estimation and Salience Effects, American Economic Journal: Applied Economics, Vol. 2, No. 3, pp. 180-212.

Scholz, J.K. (1993). The Earned Income Tax Credit: Participation, Compliance and Antipoverty Effectiveness, September 1993, Institute for Research on Poverty discussion paper no. 1020-93, University of Wisconsin Institute for Research on Poverty.

Verboon, P. and Van Dijke, M. (2007). A Self-Interest Analysis of Justice and Tax Compliance: How Distributive Justice Moderates the Effects of Outcome Favourability, Journal of Economic Psychology, Vol. 28, No. 6, pp. 704-727. 